\title{
Impact of Investment, Trade and Income per Capita on the Growth of the Manufacturing in Kosovo
}

\author{
Submitted 21/12/19, $1^{\text {st }}$ revision $18 / 01 / 20,2^{\text {nd }}$ revision $20 / 02 / 20$, accepted $10 / 03 / 20$
}

\author{
Nakije Kida ${ }^{1}$
}

\begin{abstract}
Abstarct:
Purpose: The purpose of this study is to measure the impact of Foreign Direct Investment (FGI), Domestic Investment (DI), Trade (T), and Income per Capita (GDPpc) on the Growth rate $(G R)$ of the manufacturing sector in Kosovo.

Methodology: Descriptive statistical analysis, Spearman's rho correlation analysis, multiple regression analysis, Likelihood Ratio Tests that include the Chi-Square test were used to validate the research hypothesis. The data were obtained from the World Bank covering the period 2004-2018, the data processing is done with the SPSS-21 software package.

Findings: The results found a positive impact of domestic investments in the manufacturing sector. Whereas, Foreign Direct Investment has a negative impact on the manufacturing sector as a result of the low reinvestment of foreign investors in this sector. Whereas, the trade coefficient is statistically significant and negative as a result of the dominance of imports of products and services and low productivity. The per capita income ratio is statistically significant and negative because of the low level of per capita income which reduces the demand for products of the manufacturing sector by increasing the demand for cheaper imported goods.

Practical implications: The results are clear imposing a strong message to policymakers to prioritize macro-fiscal policies that drive increased output, increased exports, and employment.

Originality: This paper highlights an empirical analysis based on real data obtained from the World Bank Indicator for Kosovo with previously unexplained variables.
\end{abstract}

Keywords: Manufacturing sector, domestic investment, FDI, trade, GDPpc.

JEL Codes: L6, D25, F21, F5, P44.

Paper type: Research article.

\footnotetext{
${ }^{1}$ Faculty of Economic Sciences, College AAB, e-mail: nakije.kida@ universitetiaab.com;
} 


\section{Introduction}

Kosovo has taken positive steps towards economic recovery for 20 years. It has transformed from a semi-industrialized economy into a market economy. It is the Small and Medium Enterprises (SMEs) sector that dominates about 99\% of GDP (Ministry of Trade and Industry, 2019, 7). Positive economic growth in Kosovo is a result of consumption and public investment in infrastructure. However, this low growth rate due to lack of development of the manufacturing industry in Kosovo (only $11 \%$ of GDP) has caused a low value of production and low employment. With a Gross Domestic Product of 6,725.9 million euros as it was in 2018 and economic growth at $3.82 \%$ and GDP per capita at $3,746 €$, shows a lack of a wellbeing economy (MTI, 2019).

While exports have low rates compared to imports (11\% of imports), it has caused a negative trade balance (MTI, 2019). Imports, according to trading partners in 2004, were 1,063.3 million, while in 2019 they increased to 3,497.1 million euros. There have never been serious policies that help exports in Kosovo. While exports in 2004 were 56.6 million the Euro regime has increased the sector only to 383.5 million euros in 2019 (CBK, 2019). If we refer to the figures from the Ministry of Trade and Industry of 2018, regarding the participation of the manufacturing industry in general exports, it is $70.27 \%$, while in general imports it is $93.27 \%$ (MTI, 2019).

About half of the enterprises in this sector are active in the production of clothing, followed by the production of textiles and leather products. Textile manufacturing enterprises are concentrated in the regions of Prizren, Gjakova, and Pristina. In 2018, FDI in the manufacturing sector suffered a decrease of 16.7 million, according to Central Bank Kosovo (CBK, 2019). Kosovo faces excessive informality, unskilled labor, lack of finances, and a high level of corruption.

\section{Literature Review}

The paper discusses the implications of different determinants in the growth of the manufacturing sector in Kosovo. Over the past two decades, Kosovo's economic integration between countries has deepened through increased participation in global markets for capital, goods, and services. In this context, corporate investments in Kosovo have not played their part in financing the manufacturing sector.

Different authors have dealt with micro and macro variables that have increasing effects of Foreign Direct Investment (FDI) in the sectors of the economy and in particular in the manufacturing sector as:

- Afaro (2003), in his study, emphasizes that FDIs in the primary sector tends to have an increasingly negative effect, while investment in manufacturing has a positive effect, while evidence from the services sector is unclear. 
- Findlay (1978) emphasized the importance of FDI as a channel for the transfer of technology, that has to do with the inflow of foreign investment in the manufacturing and services sector and not in the primary sector.

- Nguyen Tan Vinh (2019) researched the impact of FDI and human capital on Vietnam's labor productivity. The research result shows that FDI has a positive effect on labor productivity in the short and long term.

- Poldahl (2006) found that a firm's decision to invest in the manufacturing sector is related to factors such as firm ownership and variables such as human capital, capital intensity, and intensity in the use of energy.

- Bellak, Leibrecht, and Stehrer (2008) found that research and development expenditures, unit labor costs, employee skills, institutional environment, and tax policy, contribute to the growth of the manufacturing sector.

- Jindrichovska et al. (2020) analyzed the trend of FDIs and their effect to institutional environment in the Czech Republic.

\section{Methodology}

As the study addresses the problems of the manufacturing sector in Kosovo, some determinants as the Domestic Investment (Dom.Inv.), GDPpc, Trade, and FDI, have been selected which can be considered to increase productivity. Secondary quantitative data from the World Bank, 2019 for the period 2004-2018 are processed with SPSS-21. Variables are in millions of dollars and converted per capita.

Ordinary Least Squares (OLS) model, multiple regression technique, Spearman correlation, descriptive statistical methods are used. The least-squares method is usually credited to Carl Friedrich Gauss (1795), but it was first published by AdrienMarie Legendre (1805), Cohen, Cohen, West, and Aiken (2003). The OLS model, through the theoretical equation, is as follows:

Manif $_{\text {it }}=\mathrm{a}_{0 \mathrm{it}}+\beta_{1}$ Dom.Inv. it $+\beta_{2}$ GDPpc $_{\text {it }}+\beta_{3}$ TRADE $+\beta_{4}$ FDI $+\varepsilon_{\text {it }}$

Where: GDPgpc = GDP per capita; FDI = Foreign Direct Investment \%GDP; DOM.INV.= Domestic Investments \%GDP; TRADE $=$ Trade \%GDP; iit $=$ random error.

Determination coefficient $\mathrm{R}^{2}$, standard coefficient error, $\mathrm{t}$-statistics, ratio $-\mathrm{F}$, and other important econometric tests are performed to assess the relative importance and reliability of estimating the model parameters and to test the research hypothesis:

Research Hypothesis: Domestic investment, GDP per capita, Trade and Foreign Direct Investment in Kosovo have had a positive impact on the growth of the manufacturing sector in Kosovo. 
In addition to the contribution (familiarity with the determinants of growth of the manufacturing sector in the country) not including a wide range of variables is considered a limitation.

\section{Results}

Descriptive analysis in Table 1 is done to examine the determinants of FDI in Kosovo. First, it is found that the values of the variables manufacture around the average are more concentrated than other variables because the distribution of values is 0.46 units from the average, 10.93 units, this distribution is the lowest.

Table 1. Descriptive Statistics

\begin{tabular}{|c|c|c|c|c|c|c|c|c|c|c|}
\hline & \multirow{2}{*}{$\begin{array}{l}\text { N } \\
\text { Statisti } \\
\mathrm{c} \\
\end{array}$} & \multirow{2}{*}{$\begin{array}{l}\text { Minim } \\
\text { um } \\
\text { Statisti } \\
\text { c }\end{array}$} & \multirow{2}{*}{$\begin{array}{l}\text { Maxim } \\
\text { um } \\
\text { Statisti } \\
\text { c } \\
\end{array}$} & \multirow{2}{*}{$\begin{array}{l}\text { Mean } \\
\text { Statisti } \\
\mathrm{c} \\
\end{array}$} & \multirow{2}{*}{$\begin{array}{l}\text { Std. } \\
\text { Devia. } \\
\text { Statisti } \\
\text { c } \\
\end{array}$} & \multirow{2}{*}{$\begin{array}{l}\text { Varia } \\
\text { nce }\end{array}$} & \multicolumn{2}{|c|}{ Skewness } & \multicolumn{2}{|c|}{ Kurtosis } \\
\hline & & & & & & & $\begin{array}{l}\text { Statis } \\
\text { tic }\end{array}$ & $\begin{array}{l}\text { Std. } \\
\text { Error }\end{array}$ & $\begin{array}{l}\text { Statisti } \\
\mathrm{c}\end{array}$ & $\begin{array}{l}\text { Std. } \\
\text { Error }\end{array}$ \\
\hline MANIF & 11 & 10.26 & 12.07 & 10.93 & .46 & .218 & 1.161 & .661 & 3.567 & 1.279 \\
\hline FDI & 11 & 2.704 & 9.43 & 5.62 & 2.28 & 5.20 & .410 & .661 & -1.169 & 1.279 \\
\hline GDPpc & 11 & 1.325 & 5.24 & 2.88 & 1.09 & 1.20 & .827 & .661 & .961 & 1.279 \\
\hline GCFC & 11 & 23.23 & 30.65 & 26.92 & 2.16 & 4.68 & .147 & .661 & -.293 & 1.279 \\
\hline TRADE & 11 & 69.02 & 83.07 & 75.24 & 4.61 & 21.26 & .425 & .661 & -.836 & 1.279 \\
\hline $\begin{array}{l}\text { Valid N } \mathrm{N} \\
\text { (listwise) }\end{array}$ & 11 & & & & & & & & & \\
\hline
\end{tabular}

Source: Author.

The second best variable in terms of distribution after manufacture is GDPpc having an average of 1.09 units with an average distribution of 2.88 units, which shows that even in this case the distribution is concentrated during our analysis period. For Foreign Direct Investment, the value distribution is 2.28 units from an average of 5.62 units. This indicates that these variables have a concentrated distribution throughout the period of analysis (2004-2018). For trade, the distribution of values is 4.61 units from an average of 75.24 units. This indicates a less concentrated distribution around the mean, unlike the other variables.

Table 2, through test Kolmogorov-Smirnov, shows a normal distribution of data. Since the values of two tests, Kolmogorov-Smirnov Z (Asymp. Sig. (2-tailed) tests are 0. 881, 0.829, 0.998, 0.998, and the Exact Sig. (2-tailed) tests are 0.823, 0.763, 0.992 , and 0.994 are greater than $5 \%$, we conclude that the data distribution follows the normal distribution and the condition for performing parametric tests is met.

Table 2. One-Sample Kolmogorov-Smirnov Test

\begin{tabular}{llllll}
\hline \hline & & GDPpc & FDI & TRADE & GCFC \\
\hline $\mathrm{N}$ & & 11 & 11 & 11 & 11 \\
Normal Parameters $^{\mathrm{a}, \mathrm{b}}$ & Mean & 2.88 & 5.62 & 75.24 & 26.92
\end{tabular}




\begin{tabular}{llllll} 
& Std. Deviation & 1.095 & 2.282 & 4.610 & 2.163 \\
Most Extreme & Absolute & .177 & .189 & .119 & .116 \\
Differences & Positive & .177 & .189 & .119 & .116 \\
Kolmogorov-Smirnov Z & Negative & -.079 & -.123 & -.099 & -.079 \\
Asymp. Sig. (2-tailed) & & .587 & .626 & .395 & .384 \\
Exact Sig. (2-tailed) & & .881 & .829 & .998 & .998 \\
Point Probability & & .823 & .763 & .992 & .994 \\
\hline \hline
\end{tabular}

a. Test distribution is Normal. b. Calculated from data.

Source: Author.

Table 3, shows the model parameters for which the model adoption is calculated. The LR Chi-Square statistic can be calculated by $-2 * \mathrm{~L}$ (null model) $-(-2 * \mathrm{~L}$ (fitted model $)$ ) $=52.754-.000=52.754$, where L (null model), is from the log likelihood with just the response variable in the model.

Table 3. Model Fitting Information

Model Fitting Information

\begin{tabular}{lllll}
\hline \hline Model & \multicolumn{3}{l}{ Model Fitting Criteria } & \multicolumn{3}{l}{ Likelihood Ratio Tests } & \\
\cline { 2 - 5 } & -2 Log Likelihood & Chi-Square & df & Sig. \\
\hline Intercept Only & 52.754 & & & \\
Final & .000 & 52.754 & 100 & 1.000 \\
\hline \hline
\end{tabular}

Source: Author.

Table 4, the R-value represents the multiple correlations and is 0.890 , which indicates a high degree of correlation. Even the value $\mathrm{R}^{2}$ ( $\mathrm{R}$ Square $=0.792$ ) is high. $\mathrm{R}^{2}$ explains the growth of the manufacturing sector with independent variables the Domestic Investment, GDPpc, Trade, FDI in the period 2004-2018. This model's explanatory measure of $79 \%$ is high.

Table 4. Model Summary ${ }^{b}$

\begin{tabular}{|c|c|c|c|c|c|c|c|c|c|}
\hline \multirow[b]{3}{*}{ Model } & \multirow[b]{3}{*}{$\mathrm{R}$} & \multirow{3}{*}{$\begin{array}{l}\mathrm{R} \\
\text { Square } \\
\end{array}$} & \multicolumn{7}{|c|}{ Change Statistics } \\
\hline & & & Adjusted & Std. Error of & $\begin{array}{ll}\mathrm{R} & \text { Square }\end{array}$ & & & & Sig. $\quad F$ \\
\hline & & & R Square & the Estimate & Change & F Change & df1 & df2 & Change \\
\hline 1 & $0.890^{\mathrm{a}}$ & 0.792 & 0.653 & 0.2752614126 & 0.792 & 5.694 & 4 & 6 & 0.031 \\
\hline
\end{tabular}

a. Predictors: (Constant), GCFC, GDPpc, TRADE, FDI

b. Dependent Variable: MANIF

Source: Author.

Table 5, shows that the regression model predicts the dependent variable statistically significant. In our case, $\mathrm{p}=.031$, the regression model statistically predicts results.

Tabela 5. ANOVA

\begin{tabular}{lllllll}
\hline \multicolumn{1}{l}{ Model } & Sum of Squares & df & Mean Square & F & Sig. \\
\hline 1 & Regression & 1.726 & 4 & 0.431 & 5.694 & $0.031^{\mathrm{b}}$ \\
& Residual & 0.455 & 6 & 0.076 & &
\end{tabular}




$$
\text { Total } 2.180 \quad 10
$$

a. Dependent Variable: MANIF

b. Predictors: (Constant), GCFC, GDPpc, TRADE, FDI

\section{Source: Author.}

Table 6, "Coefficients" provides the necessary information to predict the growth of the manufacturing sector (MANUF) from the independent variables. It can be seen that the biggest impact on the growth of the manufacturing sector is associated with the domestic investments p-value $=0.005$ and a positive coefficient of 0.399 . Trade $\mathrm{p}$-value $=0.004$, FDI $\mathrm{p}$-value $=0.020$.

Table 6. Coefficients ${ }^{a}$

\begin{tabular}{llllllll}
\hline & & \multicolumn{2}{l}{$\begin{array}{l}\text { Unstandardized } \\
\text { Coefficients }\end{array}$} & & \multicolumn{2}{l}{$\begin{array}{l}\text { Standardized } \\
\text { Coefficients }\end{array}$} & \\
\cline { 3 - 5 } Model & B & Std. Error & Beta & t & Sig. \\
\hline 1 & (Constant) & 15.508 & 1.628 & & 9.528 & 0.000 \\
& GDPpc & -0.098 & 0.088 & -0.230 & -1.115 & 0.307 \\
& FDI & -0.280 & 0.090 & -1.367 & -3.124 & 0.020 \\
& Trade & -0.179 & 0.040 & -1.765 & -4.478 & 0.004 \\
& Dom.Inv. & 0.399 & 0.104 & 1.847 & 3.818 & 0.005 \\
\hline
\end{tabular}

a. Dependent Variable: MANIF

Source: Author.

Furthermore, we can use the values in column "B" to represent the empirical regression equation 2 for all variables:

Manif $_{\text {it }}=\mathrm{C}_{0 \mathrm{it}}+\beta_{1}$ GDPpc. $_{\text {it }}+\beta_{2} \mathrm{FDI}_{\text {it }}+\beta_{3}$ TRADE $+\beta_{4}$ DOM.IN. $+\varepsilon_{\text {it }}$

Manif $_{\text {it }}=15.508-0.098-0.280-0.179+0.399$

The production sector is positively affected by $15.35 \%$ only by domestic investments, $\mathrm{p}=.005<0.05$ and other factors outside the model. The impact of FDI on the manufacturing sector is negative (coefficient -0.280) and has little statistical significance $\mathrm{p}$-value $=0.020$, which means that the added value of FDI is invested elsewhere. Whereas, the trade coefficient is statistically significant and negative (coefficient -0.179 and positive $\mathrm{p}=.004<0.05$ ), which means that it does not stimulate the growth of the production sector but other sectors because imports of products and services dominate from abroad and there is very little productivity. The per capita income coefficient is also negative and is not statistically significant (coefficient -0.098 and positive $\mathrm{p}=0.307>0.05$ ) which expresses the low level of income in purchases in this sector by consumers. 
Table 7. Correlations Bivariate ${ }^{b}$

\begin{tabular}{|c|c|c|c|c|c|c|c|}
\hline & & & $\begin{array}{l}\text { MANI } \\
\text { F }\end{array}$ & FDI & GDPpc & TRADE & GCFC \\
\hline \multirow{10}{*}{$\begin{array}{l}\text { Spearm } \\
\text { an's rho }\end{array}$} & \multirow{2}{*}{$\begin{array}{l}\text { MANI } \\
\text { F }\end{array}$} & $\begin{array}{l}\text { Correlation } \\
\text { Coefficient }\end{array}$ & 1.000 & .418 & -.273 & $-.527^{*}$ & .457 \\
\hline & & Sig. (1-tailed) & . & .100 & .209 & .048 & .005 \\
\hline & \multirow{2}{*}{ FDI } & $\begin{array}{l}\text { Correlation } \\
\text { Coefficient }\end{array}$ & .418 & 1.000 & .036 & -.355 & $.555^{*}$ \\
\hline & & Sig. (1-tailed) & .100 & . & .458 & .142 & .003 \\
\hline & \multirow[t]{2}{*}{ GDPpc } & $\begin{array}{l}\text { Correlation } \\
\text { Coefficient }\end{array}$ & -.273 & .036 & 1.000 & .409 & .373 \\
\hline & & Sig. (1-tailed) & .209 & .458 & . & .106 & .129 \\
\hline & \multirow{2}{*}{$\begin{array}{l}\text { TRAD } \\
\text { E }\end{array}$} & $\begin{array}{l}\text { Correlation } \\
\text { Coefficient }\end{array}$ & $-.527^{*}$ & -.355 & .409 & 1.000 & .400 \\
\hline & & Sig. (1-tailed) & .048 & .142 & .106 & . & .111 \\
\hline & \multirow[t]{2}{*}{ GCFC } & $\begin{array}{l}\text { Correlation } \\
\text { Coefficient }\end{array}$ & .164 & $.555^{*}$ & .373 & .400 & 1.000 \\
\hline & & Sig. (1-tailed) & .315 & .038 & .129 & .111 & \\
\hline
\end{tabular}

*. Correlation is significant at the 0.05 level (1-tailed).

b. Listwise $\mathrm{N}=11$

Source: Author.

Table 7, represents the partial correlation between the variables and this correlation is strongly positive, $\mathrm{p}=.003<0.05$ and $\mathrm{r}^{2}$ of $0.555^{*}$, between FDI and domestic investment. There is also an important relationship between the production and the domestic investment, $\mathrm{p}=0.005>0.05$ and $\mathrm{r}^{2}=0.457$, while the relationship between trade and the manufacturing sector is negative $r^{2}=-0.527 *$ and is not statistically significant, $\mathrm{p}=0.048<0.05$. The same is the relationship between GDPpc-Manufac.

\section{Conclusions}

Regarding the results of possible determinants of growth in the manufacturing sector, it is worth noting that the variable domestic investments have had a positive impact on growth. Meanwhile, FDI has been found to have a negative impact on the manufacturing sector as a result of the low reinvestment of foreign investors in this sector and low net FDI inflows for 17 years. Whereas, the trade coefficient is negative and statistically significant as a result of the dominance of imports of products and services, and low productivity.

The lack of wider involvement in the foreign trade of local firms has reduced the possibility of benefits in expertise and machinery. Also, the per capita income coefficient is statistically significant but negative, the consumers of Kosovo are directed to imported products. In summary, our results suggest that it is important to favor foreign and domestic investors, through economic and fiscal policies in favor 
of their investment projects in the manufacturing sector. Also, the creation of a concrete sector strategy and transparency in investments will attract sustainable investors in the manufacturing sector.

\section{References:}

Alfaro, L. 2003. Foreign Direct Investment and Growth: Does the Sector Matter? Harvard Busines School. http://www.people.hbs.edu/lalfaro/fdisectorial.pdf.

Barro, R.J. 1990. Government Spending in a Simple Model of Endogeneous Growth. Journal of Political Economy, 98, S103-S125. https://doi.org/10.1086/261726.

Bellak, C., Leibrecht, M., Stehrer, R. 2008. Policies to attract Foreign Direct Investment: An industry-level analysis. FIW Research Report Nº 019 June. The Vienna Institute for International Economic Studies.

http://citeseerx.ist.psu.edu/viewdoc/download?doi=10.1.1.353.6582\&rep=rep1\&typ $\mathrm{e}=\mathrm{pd}$.

Central Bank of Kosovo. External Sector Statistics, Balance of Payments-components. https://bqk-kos.org/statistikat/serite-kohore/.

Cohen, J., Cohen, P., West, S., Aiken, L. 2003. Applied multiple regression/correlation analysis for the behavioral sciences. Hillsdale, NJ, Lawrence Erlbaum Associates.

Findlay, R. 1978. Some Aspects of Technology Transfer and Direct Foreign Investment. The American Economic Review, 68(2), 275-279. Retrieved from: www.jstor.org/stable/1816704.

Jindrichovska, I., Ugurlu, E., Thalassinos, I.E. 2020. Exploring the Trend of Czech FDIs and their Effect to Institutional Environment. International Journal of Economics and Business Administration, 8(1), 94-108. DOI: 10.35808/ijeba/411.

Ministry of Trade and Industry. 2018. Report: Sector C - Manufacturing Industry. https://mti.rks- gov.net/desk/inc/media/.

Nguyen Tan Vinh. 2019. The Impact of Foreign Direct Investment, Human Capital on Labour Productivity in Vietnam. International Journal of Economics and Finance, Vol. 11, No. 5. Published by Canadian Center of Science and Education. https://pdfs.semanticscholar.org/.

Poldahl. 2006. Domestic vs. International Spillovers: Evidence from Swedish Firm Level Data. J Ind Compet Trade 6, 277-294. https://doi.org/10.1007/s10842-006-8428-4 https://link.springer.com/.

World Development Indicators. 2019. Time series for Kosovo Country. https://databank.worldbank.org/source/world-development-indicators.

UCLA. Statistical consulting. Multinominal logistik Regression, SPSS-Anotated output. https://stats.idre.ucla.edu/spss/output/multinomial-logistic-regression/. 